\title{
Developing the Students' English Listening Skill by Applying Drama Movies Viewing Techniques
}

\author{
Suramto \\ Universitas Musi Rawas \\ Suramtosragen68@gmail.com
}

\begin{abstract}
Listening is one of fundamental skills in English. Unfortunately, most students are not able to achieve listening skill well. There are many factors that influence students? listening skill is low. This research tried to solve the problem regarding the students' difficulities in achieving listening skills by using drama movies reviewing technique this study is a quasi experimental design. The object of this paper were 30 students' of students of general conversation Classes. The data were collected by using listening achievement test. The results showed that the students who were treated by the techniques of viewing drama movies achieved higher mean score in listening skill (81.46). The techniques of viewing drama movies also gave contribution in listening skill (61.8\%).
\end{abstract}

Keywords: drama movies viewing techniques and listening skill

\section{INTRODUCTION}

Listening is one of important skills in English mastering. Listening skill is usually studied in the first step while children, teenagers, and adults start learning English. Listening is introduced and taught effectively at the beginning in order the students are able to achieve English skill as well as the target of learning process. Furthermore, the students are able to understand largely in education. According to Saricoban $(1999$, p.6) listening is one of the fundamental language skills. It is a medium through which children, young people and adults gain a large portion of their education, their understanding of human affairs, their ideals, sense of values and their appreciation. 
In addition, Brown (1980, p.43) states a child listens and speaks and no one would dream of making read or write. Reading and writing are advanced stages of language development. The natural order for first and second language learning is listening, speaking, reading, and writing. In other words, listening is studied by the children for first step, and the next steps they are going to learn speaking, reading, and writing skills. It means that the children usually are going to learn speaking, reading, and writing after they learned listening skill.

Listening is one of fundamental skills in English. Unfortunately, most students are not able to achieve listening skill well. There are many factors that influence students' listening skill is low. Monotonous learning media, speaking speed, and limited vocabulary are usually faced the students. Stivani and Hayati (2011) conducted a research entitled Using Animation Clips to Improve the Listening Ability of the Eight Graders of SMP Negeri 21 Malang. She found that 52\% of students could not reach the SKM and 93\% of students said that the media used in the class is monotonous. Handayani (2009) conducted a research entitled The Problems of Learning English at SMP Negeri 9 Malang. She found that listening was the most difficult faced the students in English, and $89 \%$ of the students said that they found problems of learning listening. The students' problems in listening are about speaking speed and limited vocabulary.

Most students complain that from four English skills, listening is the most difficult. They usually blame the recording as the only problem in their listening. There are many problems affect the listening skill. According to Underwood (1990, p.16), there are seven potential problems that students may encounter while learning to listen to English. Three of them are; the students are not able to get things repeated; the students have limited vocabularies; and the students are lack of control over the speed at which the speakers speak. The problem of English listening skill also happens to the students of general English classes although not all problems are experienced by all of them. The increasing of students' listening skill can be conducted by the techniques of viewing movies. Hence, students are able to achieve listening skill well. In practicing process, the teacher is able to provide and apply the teaching aids properly. Movie is one of media in increasing students' listening skill. In according to Hemei (1997, p.45), video movie usage is a great help for foreign language teachers in stimulating and facilitating the target language. In addition, Whatley (2012, p.51) states that the presence of film and video changes the learning atmosphere of the class, 
as ESL/EFL students are hearing authentic English in real life scenes and natural settings.

In developing students' listening skill, the teacher is able to use movies as a great media and a positive influence to the students. It can be suitable teaching device in English learning as the target language. Rubin (1995, p.157) states using movie can help students develop cognitive strategies. While they view a segment through sound off, the students can be asked to make predictions about what is happening by answering questions and while viewing the segment through sound on, the students are able to modify their predictions. In other words, the students are able to predict what is happening while they are watching movie through sound off and they are able to verify while they are watching movie through sound on.

The use of movies will be beneficial. Harmer (2007, p.144) points out using video movie can be much richer than using audio. Video movie does not only produce sound but also produce moving picture; speakers can be seen, their body movements give clues as to meaning; so do their clothes they wear, their location, and background information can be filled in visually. In other words, while the students are watching movies, they are assisted by the speakers' gesture, they know what happen, and they know where the activity is happened. In other words, the students will have good skill in listening. Then, it is for this purpose that the present study is carried out. More straightforwardly, the present research is intended to find the answers to the following research problems;

1. Is there any significant difference in listening skill between the students of general conversation classes Global Prestasi English Language Center Lubuklinggau who are taught listening by the techniques of viewing drama movies and those who are not?

2. How much contribution is the technique of viewing drama movies toward students' listening skill of general conversation Global Prestasi English Language Center Lubuklinggau?

\section{THEORITICAL FRAMEWORK \\ Students? English Listening Skill}




\section{a. The Definition of Listening}

Listening is one of the subjects studied in the field of language study and in the discipline of conversation analysis. This skill can be improved by practice and there are many rewards to develop your listening skill. It is the active process of receiving and responding to spoken (and sometimes unspoken) messages. Helgesen(2003,p.24)States that listening is an active,purposeful process of making sense of what we hear. More often we hear, more we can understand something. Regarding that citation, although listening is receptive, it is very active because listeners can think and understand things at higher levels than what they have heard. As they listen, they process not only what they hear but also connect it with other information they have already known. Since listeners combinewhat they have listened to their existing knowledge and experiences, in a very real sense,they are figuring or creating some kinds of meaning in their own mind.

Rost (2002,p.177) defines listening, in its broadest sense, as a process of receiving what the speaker actually says (receptive orientation) ; constructing and representing meaning (constructive orientation); negotiating meaning with the speaker and responding (collaborative orientation); and, creating meaning through involvement, imagination and empathy (transformative orientation). Listening, then, is a complex, active processes of interpretation in which listeners match what they hear with what they have already known.

Riversin Hasyuni (200,p.8)States that listening is a creative skill.It means we comprehend the sound falling on our ears,and take the raw material of words, arrangements of words, and the rise and fall the voice, and from this material we create significance. So,we can say that listening is like a cooking,there is the recipe,and then we gather the ingredients, start to process to cook and finally we eat that.The process will be successful if we prepare the right do,as well as listening, we can get the right words if we listen well and know all of the sentences. From the definition above,it can be concluded that listening is a complex, active process of interpretation in which listeners match what they have heard with what they have already known. 


\section{Drama Movies Viewing Techniques}

There are five steps in viewing techniques: fast forward, silent viewing (for language), silent viewing (for music), freeze frame, and partial viewing (Harmer 2007, p.309). In fast forward, the teacher presses the play button and then fast forwards the DVD or video so that the sequence shoots past silently and at great speed, taking only a few seconds. In silent viewing (for language), the teacher plays the film extract at normal speed but without the sound. In silent viewing (for music), the same technique can be used with music. In freeze frame, at any stage during a video sequence we can "freeze" the picture, stopping the participants dead in their tracks. In partial viewing, one way of provoking the students" curiosity is to allow them only a partial view of the pictures on the screen.

\section{Pre-ViewingTechniques}

It is a common practice in instructions on language decoding (including listening) that at this beginning stage the teacher spends a sufficient amount of time helping the learners build the appropriate schemata to facilitate comprehension (van Duzer, p. 1997). This view focuses on the use of the prior knowledge in watching the films. It can be implemented through five techniques of film clips by identifying the theme and key words. This conceptually-driven style of teaching are believed to enable the learners to proceed a, hook"thatrelates the knowledge he already possesses and the one to be acquired, making the acquisition occur more smoothly. Generally the previewing stage consists of two activities, namely, introducing the theme of the movie and pre-teaching the key vocabulary working within this framework, at the beginning of the session (Kusumarasdyati 2004, p. 5).

It focuses on describing the theme that underlies the whole plot of the movie, and also the presence or the absence of subtitles in the mother tongue. After that, I"ll give a worksheet and an answer sheet, and have the learners scan the items in the worksheet for a few a minutes to familiarize themselves with the learning activities to be carried out before, during and after viewing the movie. If the film includes subtitles, the learners proceed to the while- viewing stage and do not need to discuss the keywords because lexical items will be a part of the while-viewing activities. However, if the subtitles are absent, I review a number of keywords from the movie to cater for a scaffold that will assist them in the comprehension later. 
Otherwise, the learners need to expend extra effort to understand what is happening in the movie and may give up disheartened if they fail to do so. Rather than simply telling them the meaning of these keywords, I prefer presenting them in sentences and asking the students to perform intelligent guessing to figure out the meaning of each on the basis of the context. Retention is expected to be better if they discover the meaning themselves.

\section{While-Viewing}

In while-viewing, learners listen by doing some comprehension questions (Kusumarasdyati 2004,p. 6). It can be indicated by the existence of the subtitles. If there is a subtitle, the comprehension questions are simple which consists of language functions and specific information such as names, times, specific language forms and etc. In contrast, if there is no subtitle in the film, the comprehension questions are more complex which consists of gist listening such as identifying main ideas, noting a sequence of events and the like. Teachers guide the students by giving the knowledge of note taking techniques. Note-taking is a meaning-focused listening activity. It is also an essential skill for academic study where learners have to attend lectures in another language, but can be used in various forms at all levels of language proficiency (Richards: 2008). The use of note taking helps students to adsorb the information to answer the comprehension questions. This technique can be implemented through freeze frame and partial viewing.

\section{Post-Viewing}

In post-viewing, the activities focus on what the learners have done in watching the film (Kusumarasdyati, 2004: 8). The activities can be the sequence of language features. It can be indicated after learners finishing their notes. Then, they may complete to tell by using their own words in arranging thewords.

\section{RESEARCH METHODHODOLOGY}

A quasi experimental design (non-equivalent group pretest-posttest design) was used in this study. The objects of the study were sixty students of general conversation at Global Prestasi English Language Center Lubuklinggau South Sumatera. They consisted of thirty students in the experimental and thirty students in control groups. The experimental group was given pre-test and post-test, treatment 36 meetings started on September 8, 2018 up to January 8, 2019. 
Meanwhile, the control group was given pre-test and post-test. The instrument for data collection is listening skill test. There were 40 multiple choice questions in the listening skill test sheet.

In this study, there are two variables: (1) The technique of viewing drama movies; and (2) students' listening skill. Technique of viewing drama movies means a movie about people, often a famous story and that is told using sound and moving pictures. It is used for teaching listening. This is a teaching device in assisting the students' comprehension by enabling them to listen, to exchange and see such visual support as facial expressions and gestures simultaneously which may boost their insight into the topic of conversations. Students' listening skill means that the scores are achieved by the students after they received treatment. The achievement here means the skill of listening in English that students are able to know information listening program from the speakers. The students' listening skill in this study is limited to the basic skill of the students' scores in pre-test and post-test.

Technique for analyzing the data used in this research was listening skill test. The t-test analysis was used to find out the significant difference in students' listening skill. There are two kinds of t-test analysis used in this study: dependent sample t-test and independent sample t-test (Best and Kahn, 1993, p. 328-341). First, Dependent sample t-test was used to analyze the significant influence on listening skill of the students general conversation Global Prestasi English Language Center Lubuklinggau before and after they were taught listening by the technique of viewing drama movies. Second, Independent sample t-test was used to analyze the contribution of listening skill between the students of general conversation Global Prestasi English Language Center Lubuklinggau who are taught listening by the techniques of viewing drama movies and those who are not. SPSS program was used to analyze it.

\section{FINDINGS AND DISCUSSIONS Findings}

The post-test result of listening skill in the experimental group and control group are presented in table 1 . 
Table 1.

Frequency and Mean of Students' Listening skill Test Based on

Achievement Level

\begin{tabular}{|c|c|c|c|c|}
\hline Variables & $\begin{array}{c}\text { Level of } \\
\text { Achievement }\end{array}$ & Mean & $\begin{array}{c}\text { Frequency } \\
\text { and } \\
\text { Percentage }\end{array}$ & $\begin{array}{c}\text { Std. } \\
\text { Deviation }\end{array}$ \\
\hline \multirow{7}{*}{$\begin{array}{l}\text { Listening } \\
\text { Skill Test } \\
\text { (LST) }\end{array}$} & $\begin{array}{l}\text { Very Limited } \\
\text { Listener }\end{array}$ & - & -1 & - \\
\hline & $\begin{array}{l}\text { Limited } \\
\text { Listener }\end{array}$ & - & - & - \\
\hline & $\begin{array}{c}\text { Marginal } \\
\text { Competent } \\
\text { Listener }\end{array}$ & - & - & - \\
\hline & $\begin{array}{c}\text { Competent but } \\
\text { Limited } \\
\text { Listener } \\
\end{array}$ & 68.93 & $14(23.33 \%)$ & 1.616 \\
\hline & $\begin{array}{l}\text { Competent } \\
\text { Listener }\end{array}$ & 76.44 & $26(43.33 \%)$ & 3.096 \\
\hline & Adept Listener & 84.75 & $20(33.34 \%)$ & 2.678 \\
\hline & $\begin{array}{c}\text { Expert } \\
\text { Listener }\end{array}$ & & - & - \\
\hline TOTAL & & 230.12 & $60(100 \%)$ & 7.390 \\
\hline MEAN & & 76.71 & - & 2.463 \\
\hline
\end{tabular}

The listening skill, the students' mean scores for competent but limited listener, competent listener, and adept listener categories were $68.93,76.44$, and 84.75 respectively. Furthermore, the students' mean score of listening skill was 76.71 . It can be concluded that the mean score of the students' listening skill was in competent listener category or good level.

In the terms of frequency and percentage in students' listening achievement, the results of the listening skill test showed that there were 14 students $(23.33 \%)$ who were in competent but limited listener, 26 students (43.33\%) who were in competent listener, and 20 students (33.34\%) who were in adept listener. There were 46 students (76.67\%) who were in competent listener and adept listener categories. It could be said that the students' listening achievement was good because the percentage of students' listening achievement is more than $75 \%$.

There were two statistical analyses in this study; Dependent sample 
t-test (paired sample t-test) and multiple regressions. Dependent sample $t$-test (paired sample t-test) was used to find out: (1) the significant difference in students' listening achievement before and after the students was taught by the technique of viewing drama movies. Independent sample t-test was used to find out: (1) the significant difference in students' listening achievement between the experimental and control groups. Multiple regression analysis was used to find out the contribution by the techniques of viewing drama movies of students' listening skill. The table below showed the results of Paired Sample and Independent Sample t-test analysis.

Table 2.

The Results of Paired Sample and Independent Sample t-test

\begin{tabular}{|l|l|l|l|l|l|}
\hline Strategy & Variable & \multicolumn{2}{|c|}{ Pre-test } & \multicolumn{2}{c|}{ Post-test } \\
\hline Drama & & & & & \\
Movies & Listening & 70.16 & 72.31 & 81.46 & 73.38 \\
$\begin{array}{l}\text { Viewing } \\
\text { Techniques }\end{array}$ & Skill Test & & & & \\
\hline
\end{tabular}

\begin{tabular}{|c|c|c|c|}
\hline $\begin{array}{c}\text { Mean } \\
\text { difference } \\
\text { pre and } \\
\text { posttest } \\
\text { Exp } \\
\text { within }\end{array}$ & $\begin{array}{c}\text { Mean } \\
\text { difference } \\
\text { pre and } \\
\text { posttest } \\
\text { Cont } \\
\text { within }\end{array}$ & $\begin{array}{l}\text { T-value } \\
\text { posttest } \\
\text { between } \\
\text { Exp and } \\
\text { Control }\end{array}$ & $\begin{array}{l}\text { T- value } \\
\text { of Gain } \\
\text { between } \\
\text { Exp\& } \\
\text { Control }\end{array}$ \\
\hline 1 & 2.667 & 0.018 & 10.521 \\
\hline
\end{tabular}

\begin{tabular}{|c|c|c|}
\hline $\begin{array}{c}\text { The value } \\
\text { of Sig.2- } \\
\text { tailed } \\
\begin{array}{c}\text { Exp } \\
\text { within }\end{array}\end{array}$ & $\begin{array}{c}\text { The value } \\
\text { of Sig.2- } \\
\text { tailed } \\
\text { Contwithin }\end{array}$ & $\begin{array}{c}\text { The value } \\
\text { of Sig.2- } \\
\text { tailed } \\
\text { between } \\
\text { Exp and } \\
\text { Control }\end{array}$ \\
\hline .000 & .017 & .000 \\
\hline
\end{tabular}

Based on the table above, the results showed that the mean difference of listening skill in the experimental group was 11.300. The value of $d f$, t-obtained, and the value of sig.2-tailed were 29, 3.045 (>ttable), and $0.00(<0.05)$. If the value of t-obtained $>\mathrm{t}$-table and sig.2tailed $<0.05$, it means there was a significant difference between the 
pretest and posttest of students' listening achievement in the experimental group. It could be stated that teaching listening by the technique of viewing drama movie was effective in the experimental group.

Furthermore, the terms of listening achievement, the mean difference was 2.667. The value of degree of freedom $(d f)$, t-obtained, and the value of sig.2-tailed were 29. (2.524) and .017. It means teaching listening without using the technique of viewing drama movie was also effective although the improvement in students' listening scores was not as higher as the scores in the experimental group. In terms of students' listening achievement, the $t$-value of gain between the experimental and control group was 10.521 . The value of degree of freedom $(d f)$ was 58 , tobtained was 6.018 (>2.021), and the value of sig.2-tailed was .000. It means the value of t-obtained was higher than t-table and the value of sig.2-tailed was lower than 0.05 . It could be said that the techniques of viewing drama movies significantly develop students' listening skill. After he found the significant in the technique of viewing drama movies to listening skill, he also found the contribution. Multiple regression analysis was used to know the contribution in the technique of viewing drama movies towards listening skill.

Based on the result, it can be concluded that the techniques of viewing drama movies could give contribution to students' listening achievement namely $61.8 \%$. In terms of listening achievement, the students' mean scores of the techniques of viewing drama movies in listening skill were to identify words meaning $(0,75)$, to express idea (0.73), to respond satisfied and unsatisfied (0.96), to express feeling $(0.96)$, to identify request $(0.91)$, to respond agreement $(0.90)$, to identify advice (0.81), to identify topics $(0.90)$, to identify the goal of function text $(0.83)$, to identify main idea $(0.67)$, and to identify the cases (0.43), so it could be concluded that the use of the techniques of viewing drama movies gave high contribution for the skill of expressing feeling and responding satisfied.

\section{Discussions}

In this study, the researcher applied the techniques of viewing drama movies in teaching to the students of general conversation class Global Prestasi English Language Center Lubuk linggau. The results of this study showed that the techniques of viewing drama movies significantly develop the students' listening achievement. It can be seen the mean scores between pre-test and post-test (70.16-81.46). It means that there was an improvement in the experimental group. It is in line 
with a study done by Kusumarasdyati (2004) she found that movies could be an effective teaching device to develop the English foreign learners' listening aroused their motivation and their potential to engage in various activities. In addition, Bahrani and Sim (2012) state movies as one type of authentic audiovisual program and the result can improve language proficiency. Sulistyowati (2011) states that the use of movie can improve listening comprehension and the students' listening could be categorized good. The significant difference between students' listening achievement in both groups might be caused by the teaching technique, materials, and media used during the teaching and learning process. The writer used laptop, sound system, and LCD. This study confirms what was found by Tinio $(2012$, p.7) who states that the use of ICT by the teacher in the classroom can impact the students' learning achievement. Furthermore, Dudeney and Hockly (2007, p.7-8) state that the use of ICT by language teachers in the classroom is becoming increasingly important and it will become a normal part of ELT practice. Using a range of ICT can give students exposure and practice in all of the four main language skills; listening, speaking, reading, and writing.

The mean score of the students' listening skill in in experimental group was 80.5781 .46 (adept listener category or very good). Hence, it can be said that the students were in good category if the mean scores of the students' listening achievement higher than $\geq 75$. It can be concluded that the mean score of the students' listening achievement already fulfilled the standard scores of Global Prestasi English Language Center Lubuklinggau but it did not fulfill the researcherr's expectation $(\geq 85.0)$. The researcher assumes that there are some factors such as; the time of the study was limited, the treatment was only conducted in 36 meeting included pre-test and post-test, the teaching learning process was implemented in the afternoon (extra class) at 04.30 p.m. up to $06.00 \mathrm{p} . \mathrm{m}$. because the writer did not want to disturb students' learning schedule in the class, and the students were so tired because it's based on the schedule of learning in the class. Therefore, the students' results are not as high as expected by the researcher. The researcher believes that if the treatment and listening test are done in the morning class, there will be a higher improvement in students' listening skill.

The mean scores of students' listening achievement in control group was 73.38 (competent listener category or good). The terms of listening achievement, the students' mean scores between pre-test and post-test (70.16-73.38). The mean scores of listening achievement 
improved but it did not fulfill the standard of Global Prestasi English Language Center Lubuklinggau. The small improvement may be influenced by the technique or media who the teacher used in the teaching and learning process. The English teacher teaches students without using ICT. Meanwhile, teaching device is part of teaching learning process in the classroom. Tinio (2012) states the use of ICT by the teacher in the class can impact the students' achievement. In addition, Dudeney and Hockly (2007, p.7-8) state the use of ICT by the teachers in the classroom is becoming increasingly important and it will become a normal part of ELT practice.

Furthermore, the researcher also found that the techniques of viewing drama movies gave contribution to listening achievement. In terms of listening achievement, the techniques of viewing drama movies gave development in students' listening achievement of competent but limited listener category. It could be seen from the results in the listening achievement test, the results showed that there were 26 students $(86.67 \%)$ increased in adept listener category. It could be said that from 30 students, there were only 4 students $(13.33 \%)$ who could not achieve listening skill. It is clear that the techniques of viewing drama movies could develop the students' listening skill. It is supported the study done by Kusumarasdyati (2004) which found that movie could be an effective teaching device to develop the English foreign language learners' listening aroused their motivation. Similarly, Bahrani and Sim (2012) they found that films or movies through good story lines seem to motivate the learners to absorb the language input better and have a significant effect on the language improvement. The results of the study showed that there was a significant improvement of the students' listening skill in the experimental group. The techniques of viewing drama movies could enlarge the students' understanding and acknowledgment about English skills and culture.

\section{CONCLUSIONS AND SUGGESTIONS}

Based on the findings and statistical analysis in this study as explained previously, it can be taken conclusions as follows;

First, the techniques of viewing drama movies significantly develops the students' listening skill. In the experimental group, it showed from the students' score after the treatment by applying the techniques of viewing drama movies in teaching and learning process, the results of the post-test was better than the results of the pre-test (81.46>70.16). In the control group, it was found that there was lower significant mean difference than the mean difference in the 
experimental group $(73.38<81.46)$. The students' mean score of listening achievement (81.46) in the experimental group had already fulfilled the standard score of school but it was not happened by the control group (73.38). The result also showed that there was a significance mean difference between students' listening achievement in the experimental group and control group (10.233). In the experimental group, there were 26 students or $86 \%$ in adept listener and in competent listener categories. It can be said that the use of drama movies through viewing techniques for teaching listening in the experimental group was effective.

Second, it was found that the techniques of viewing drama movies gave significance contribution to the students' listening skill. The results showed that it gave $68.1 \%$ of listening skill in the experimental group. Based on the conclusion, the researcher would like deliver suggestion that the techniques of viewing drama movies is as one of teaching device in developing students' listening skill. It can be applied to the students of lower graders at English courses. Further research can be done to the students who learn English at hamlet or village in the area of Musirawas and Musirawas Utara regencies.

\section{REFERENCES}

Bahrani, T., \& Sim, T. S. (2012). Audiovisual news, cartoons, and films as sources of authentic language input and language proficiency enhancement. The Turkish Online Journal of Educational Technology,11(4), 56-64.

Best, J. W., \& Kahn, J. V. (1993). Research in education. Needham Heights, MA: A Division of Simon \& Schuster, Inc.

Brown, D. H. (1980) . Principles of language learning and teaching. White Plains, NY: Prentice-Hall.

Dudeney, G., \& Hockly, N. (2007). How to teach English with technology. Harlow, UK: Pearson Education Ltd.

Handayani, D. N. (2009). The problems of learning English at SMPN 9 Malang. (Unpublished thesis) Malang: State University of Malang.

Harmer, J. (2007). The practice of English language teaching. Harlow, UK: Pearson Education Ltd.

Hemei, J. (1997) . Teaching with video in an English class. Journal of English Teaching Forum, 35(2), 45-47. 
Kusumarasdyati. (2004). Listening, viewing and imagination: movies in EFL class. In the proceeding of the $2^{\text {nd }}$ International Conference on Imagination and Education. (pp. 1-10), Monash University, Australia.

Rubin, J. (1995) . The contribution of video to the development of competence in listening. A guide for teaching of second language listening. San Diego, CA: Dominie Press.

Saricoban, A. (1999). The Teaching of Listening. The Internet TESL Journal, 5(12). Retrieved form (http://iteslj.org/Articles/SaricobanListening.html).

Stivani, R., \& Hayati, N. (2011) . Using animation clips to improve the listening ability of the eight graders of SMP Negeri 21 Malang. (unpublished thesis) Malang: State University of Malang.

Sulistyowati, T. (2011). The impact of teaching listening comprehension by audio and audio picture aids on the $3^{\text {rd }}$ semester students' listening proficiencies of English education department students of Muria Kudus University in the academic year 2009/2010. Journal of social and culture,4(2). Retrieved from http://jurnal.umk.ac.id/?page id=1556

Tinio, L., V. (2012). ICT in Education. New York: Stephen Brown Group Leader. Retrieved from http://www.saigontre.com/FDFiles/ICT in Education. PDF on March 20,2012.

Underwood, M. (1990). Teaching listening: Longman handbooks for language teachers. London: Longman.

Watley, H. D. (2012). The effective use of motion pictures in the ESL classroom. Journal of Arts, Science \& Commerce,3(2), 50-53. 